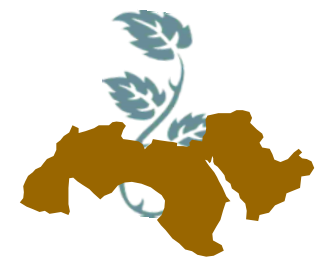

\title{
ADOPTION ASSESSMENT OF NUTRITIONAL TECHNOLOGIES BY DAIRY CATTLE SMALLHOLDERS
}

\author{
Atwa $^{1}$, S.E.; M.A. Elwardani ${ }^{2}$; Amal, S. Omar ${ }^{1}$; H.S. Soliman ${ }^{2}$ \\ and H.M. El-Sayed ${ }^{2}$ \\ 1- Animal Production Research Institute, Agric. Research Center, Dokki, Giza, Egypt \\ 2- Animal Production Dept., Fac. Agric., Ain Shams Univ., Cairo, Egypt
}

Keywords: Feed package, Technology, Small holders and Socio-economic

\begin{abstract}
This study aimed at characterizing nutritional packages adoption by the small dairy farmers under crop-livestock production system. The study is based on quantitative and qualitative statistical analysis. A cross-sectional random survey covered a total of 200 farmers located in 4 governorates Sharqia, Monufia, El-Fayoum, and Minya (50 each). The socio-economic analysis indicated that the illiteracy level was higher (42\%) in Minya governorate as compared to others. about half of the households (49\%) have been working full time in their farms as farmer this means that they earn their living from agriculture. Family labor represented the highest percentage being $88 \%, 92 \%$, $80 \%$, and $86 \%$ for Sharqia, Monufia, El-Fayoum, and Minya respectively. The results further indicated that farmers who used silage, hay, and green forages, have the highest animal numbers, either from indigenous cows, crossbred cows, buffaloes, sheep, goat, and donkey compared to those who do not use the nutritional packages (non-adopters). The highest percentage of dairy, heifer, fattening, and growing for crossbred cows and buffaloes was detected under silage, hay, and untraditional green forages adopters comparable to those detected under non-adopters. Sharqia governorate had the highest number and consequently percentage of animals followed by El-Fayoum governorate. Silage adopters recorded the highest significant $(\mathrm{P}<0.05)$ value of daily milk yield $(\mathrm{DMY})$ and total milk yield (TMY) for indigenous cow, crossbred cow and buffalo as compared to non-adopters.
\end{abstract}

Calving interval significantly $(\mathrm{P}<0.05)$ increased for all dairy animals (indigenous cows, crossbred cows, and buffaloes) under non-adopters of nutritional packages being 387, 388.57, and 402 days for the aforementioned animals, respectively. Dairy animals reared under the Nile Delta had the highest significant DMY versus those under the Middle Egypt, where it was $4.05,8.52$, and $7.29 \mathrm{~kg}$ vs $3.76,7.74$, and $6.48 \mathrm{~kg}$ per day for indigenous cows, crossbred cows, and buffaloes, respectively. In conclusion, adopters of nutritional packages had the highest animal percent and recorded the highest productivity compared to non-adopters.

\section{INTRODUCTION}

Dairy development in developing countries played an essential role in increasing milk production, increasing income in rural area, creating an employment opportunities and improving villagers nutritional status, particularly poor and marginal farmers. The dairy technologies include the use of crossbred animals, improved feed technology and improved management (Mohamed et al 2004). But dairy cattle farming in rural Egypt are composed mainly from smallholder traditional mixed farming system being managed in traditional ways. The effect of many technical (artificial insemination, vaccination, breeds, etc) and social factors would be beneficial to improve the dairy production. Understanding the adoption of dairy technologies is crucial for development success and accomplishment of policies and programs in dairy development under rural conditions. Egypt is characterized by mixed farming system; over $90 \%$ of livestock population is concentrated in small farms (Shalaby et al 2005). 
The best strategy for attaining food security is the agricultural growth, because agriculture is crucial to the livelihood and nourishment of more than half of the world's population (Adekambi et al 2009). Agricultural growth can decrease food insecurity through increasing the available quantity of food consumption. This is mainly vital for rural villagers whose food is mainly based on their own production. Inserting new agricultural technologies and improving management is the main role in improving the production in addition to accomplishment national food security especially in developing countries. Anyway, successful adoption of agricultural technologies especially nutritional packages might stimulate the economic growth through inter-sectoral linkage while conserving natural resources (Sanchez et al 2009).

Livestock sector plays essential role in rural economy particularly for developing countries and under the mixed crop-livestock farming system different livestock species are reared. It is worthy to note that research in animal nutrition yielded a number of technologies, which improve feed the nutritional quality (Bharathidasan et al 2007). Studies linked to feeding practices adopted by farmers and the availability of feed resources with them, may help not only in understanding the nutritional status of the animal, but also to discover the best solutions in take advantage of the full genetic potentiality of animals to make dairying work economically sustainable (Chatterjee et al 2007). Technologies adoption has a significant influence on milk yield per cow, consequently the gained profit per cow (Foltz and Chang, 2002; McBride et al 2004). Ashly (2016) Adopter households reported a pronounce decrease in daily time spent sourcing feed and reduced involvement of women and children in sourcing feed for cattle compared with non-adopter households. Therefore, there will be a potential increase in the income of household from forage establishment and feed packages adoption as a strategy to improve the living standard of smallholder cattle farmers.

Egypt still has the potential to meet the growing demand for milk, but the immediate need is to adopt and follow better technologies. To increase the country's milk output, a judicious strategy of focusing on nutritional technology should be adopted for considerable dairy development. The present study is, therefore, undertaken to know the base-line information of existing features of nutritional packages adoption by the small dairy farmers. The specific objective was to obtain reliable data including the demographic profile of the adopter, effect of nutritional packages adoption on herd composition and structure as well as the productivity of the animals.

\section{MATERIALS AND METHODS}

\section{Sampling techniques}

The study was carried out in four governorates in Egypt, two in Nile Delta region (Sharqia and Monufia) and two in middle Egypt region (Fayoum and Minya). A total of 200 small-holdings were included in the present survey (50 small-holders from each governorate). They were taken at random from those holdings that operate as mixed livestock farming system, where animal raising and crop cultivation activities are practiced in the same farm.

\section{Data collection}

A cross-sectional random survey of 200 households who raise cattle and are willing to participate in the present survey was performed through semi-structured interviews with questionnaires. In order to collect data including basic information, about social characteristics of the farmers, herd composition, herd structure, animal production, with especial focus on nutritional packages. The surveys depended on the administration of precisely designed questionnaire, providing standardized and quantifiable data that can be easily analyzed statistically (Chikura, 1999). The questionnaire was initially tested in the field and modified before extensive application. All interviews were conducted with the participation of more than one family member, so that each person could contribute with information relevant to the activities known to him.

\section{Statistical analysis}

Bivariate analysis was used to detect relationships between independent and dependent variables by chi-square procedure (Snedecor and Cochran, 1993). The data collected on milk production were statistically analyzed by the least squares procedure of the general linear model (GLM) of SAS program (SAS, 2010). The separation of means was done using the Duncan's New Multiple Range Test (Duncan, 1955) for comparisons among the significant means. The fixed model used in the analysis was: 


$$
Y_{i j k l}=\mu+R_{i}+G_{j}+P_{k}+e_{i j k l}
$$

Where:

$\mathrm{Y}_{\mathrm{ijkl}}=$ is the value of the respective variable

$\mu=$ is the overall mean of the respective variable

$R_{i}=$ is the effect due to the $i^{\text {th }}$ region, $i=1,2(1=$ Nile Delta, 2= Middle Egypt)

$\mathrm{G}_{\mathrm{j}}=$ is the effect of the $\mathrm{j}^{\text {th }}$ governorates $(\mathrm{j}=1,2 \ldots 4)$

$P_{k}=$ is the effect of the $k^{\text {th }}$ packages $\mathrm{j},(\mathrm{k}=1,2 \ldots 6)$

$e_{i j k}=$ is a random error associated with the $i j j^{\text {th }}$ observation and is assumed to be independently and normally distributed.

\section{RESULTS AND DISCUSSIONS}

\section{Social characteristics of the householders}

The majority of farmers (40\%) in Sharqia governorate have a secondary and technical schools, while most of farmers in Monufia (50\%) and ElFayoum (44\%) attained a tertiary education (college), however, the illiteracy level was higher in Minya governorate since $42 \%$ of the respondents were illiterate as shown in Table (1). Under the Nile Delta and Middle Egypt regions most farmers have a tertiary education (college) as indicated in Table (2). As a whole, about $37 \%$ of households had a tertiary education, $27 \%$ were illiterate, and $10 \%$ of them have the ability to read and write as indicated in Table (2). Quddus (2012) declared that only $22.2 \%$ of the households had higher secondary or above education. Kiptot et al (2015) revealed that about $44 \%$ of the respondents had attained secondary education while, $17.2 \%$ had a college degree and only $2.8 \%$ were illiterate.

Around $54 \%$ and $49 \%$ of the respondents in Sharqia and Monufia respectively, had permanent jobs as employees and worked on their farms as secondary jobs. On the other hand, the majority of the respondents in Minya (52\%) and El-Fayoum $(66 \%)$ worked in their farms permanently and earned their living from agriculture Table (1). It seems that about $49 \%$ of the respondents in Nile Delta worked as employees however, $59 \%$ of them in Middle Egypt worked as farmers in their land. As a whole, about half of the households (49\%) have been working full time in their farms as farmer this means that they earn their living from agriculture, i.e. have no job out of farm. However, 40 and $11 \%$ households in the studied farm have been working part time as employee and free job, respectively Table (2).
Regarding the experience level, the majority of farmers in Sharqia (68\%) and Monufia (66\%) had between 20-40 years of experience, the same trend was observed in El-Fayoum (58\%), Minya $(72 \%)$, This analysis showed that farmers participated were individuals with good experience in animal rearing Table (1). Also, Nile Delta and Middle Egypt $67 \%$ and $65 \%$ respectively as shown in Table (2).

In respect of the labor, management and labor responsibilities are performed within the same family. Such as milk, feed; haul manure, so they perform these routine tasks themselves. As farms grow more of the daily work is performed by hired personnel. Family labor represented the highest percentage being $88 \%, 92 \%, 80 \%$, and $86 \%$ for Sharqia, Monufia, El-Fayoum, and Minya respectively as shown in Table (1). The same trend was observed for region as indicated in Table (2).

\section{Herd composition}

Farmers who used silage, hay, and green forages (adopter), have the highest animal numbers, either from indigenous cows, crossbred cows, buffaloes, sheep, goat, and donkey compared to those who do not use the nutritional packages (non-adopters) as indicated in Table (3). Similar results were obtained by Khalil et al (2015) who indicated that farmers used feeding packages such as corn silage during winter or berseem hay during summer showed significant $(P \leq 0.05)$ higher animal numbers compared to those fed the traditional ration.

The data clearly showed that El-Fayoum had the highest percentage of indigenous cows (38.22 $\%)$ followed by El-Minya (31.03\%). However, Sharqia had the highest percentage of crossbred cows, buffalos, and goat being $36.52 \%, 33.59 \%$ and $34.39 \%$ followed by El-Fayoum being $27.15 \%$, $23.5 \%$, and $28.04 \%$ respectively. The highest percentage of sheep $(53.17 \%)$ was detected in ElMinya Table (3).

Regarding the herd composition under the region, the Nile Delta had the highest number of 555 crossbred cows (51.97\%) and 586 buffalo (56.89\%). While, Middle Egypt had the highest number and percentage of the rest mentioned animals as shown in Table (4). 
Table 1. Socio-economic analysis of the households under the studied governorates

\begin{tabular}{|l|c|c|c|c|c|c|c|c|}
\hline \multirow{2}{*}{ Items } & \multicolumn{2}{|c|}{ Sharqia } & \multicolumn{2}{c|}{ Monufia } & \multicolumn{2}{c|}{ El-Fayoum } & \multicolumn{2}{c|}{ Minya } \\
\cline { 2 - 9 } & $\mathbf{N}$ & $(\%)$ & $\mathbf{N}$ & $(\%)$ & $\mathbf{N}$ & $(\%)$ & $\mathbf{N}$ & $(\%)$ \\
\hline Experience levels & & & & & & & & \\
Experience >20 & 12 & 24 & 5 & 10 & 5 & 10 & 7 & 14 \\
Experience 20-40 & 34 & 68 & 33 & 66 & 29 & 58 & 36 & 72 \\
Experience <40 & 4 & 8 & 12 & 24 & 16 & 32 & 7 & 14 \\
Job & & & & & & & & \\
Employee & 22 & 44 & 27 & 54 & 10 & 20 & 21 & 42 \\
Farmer & 19 & 38 & 19 & 38 & 33 & 66 & 26 & 52 \\
Free job* & 9 & 18 & 4 & 8 & 7 & 14 & 3 & 6 \\
Education level & & & & & & & & \\
Tertiary & 16 & 32 & 25 & 50 & 22 & 44 & 11 & 22 \\
Illiterate & 9 & 18 & 13 & 26 & 11 & 22 & 21 & 42 \\
Secondary & 20 & 40 & 10 & 20 & 11 & 22 & 11 & 22 \\
read and write & 5 & 10 & 2 & 4 & 6 & 12 & 7 & 14 \\
Labor & 44 & 88 & 46 & 92 & 40 & 80 & 43 & 86 \\
Family & 6 & 12 & 4 & 8 & 10 & 20 & 7 & 14 \\
Hired & 40 &
\end{tabular}

Differences between governorates for experience level were significant $\left(\chi^{2}=58.3992, P<0.05\right)$

No significant difference between governorates for job $\left(\chi^{2}=49.6218, \mathrm{P}<0.0649\right)$

Differences between governorates for education levels were significant $\left(\chi^{2}=104.1383, P<0.05\right)$

Differences between governorates for labor were significant $\left(\chi^{2}=35.2089, P<0.05\right)$

${ }^{*}$ Artisans and traders

Table 2. Socio-economic analysis of the households under the studied regions

\begin{tabular}{|l|c|c|c|c|c|c|}
\hline \multirow{2}{*}{ Items } & \multicolumn{2}{c|}{ Nile Delta } & \multicolumn{2}{c|}{ Middle Egypt } & \multicolumn{2}{c|}{ Total } \\
\cline { 2 - 7 } & $\mathbf{N}$ & $\mathbf{( \% )}$ & $\mathbf{N}$ & $\mathbf{( \% )}$ & $\mathbf{N}$ & $(\%)$ \\
\hline Experience levels & & & & & & \\
Experience $>20$ & 17 & 17 & 12 & 12 & 29 & 14.5 \\
Experience 20-40 & 67 & 67 & 65 & 65 & 132 & 66 \\
Experience $<40$ & 16 & 16 & 23 & 23 & 39 & 19.5 \\
Job & & & & & & \\
Employee & 49 & 49 & 31 & 31 & 80 & 40 \\
Farmer & 38 & 38 & 59 & 59 & 97 & 48.5 \\
Free job* & 13 & 13 & 10 & 10 & 23 & 11.5 \\
Education level & & & & & & \\
Tertiary & 41 & 41 & 33 & 33 & 74 & 37 \\
Illiterate & 22 & 22 & 32 & 32 & 54 & 27 \\
Secondary & 30 & 30 & 22 & 22 & 52 & 26 \\
read and write & 7 & 7 & 13 & 13 & 20 & 10 \\
Labor & & & & & & \\
Family & 90 & 90 & 83 & 83 & 173 & 86.5 \\
Hired & 10 & 10 & 17 & 17 & 27 & 13.5 \\
\hline
\end{tabular}

Differences between regions for experience level were significant $\left(\chi^{2}=6.98, P=0.05\right)$

No significant difference between regions for job $\left(\chi^{2}=0.06, P=0.8025\right)$

Differences between regions for education levels were significant $\left(\chi^{2}=9.22, P=0.05\right)$

Differences between regions for labor were significant $\left(\chi^{2}=7.95, P=0.05\right)$ 
Table 3. Herd composition under the adopters of nutritional packages and non-adopters

\begin{tabular}{|l|c|c|c|c|c|c|c|c|c|c|c|c|}
\hline \multirow{2}{*}{ Items } & \multicolumn{2}{|c|}{$\begin{array}{c}\text { Silage } \\
\text { package }\end{array}$} & \multicolumn{2}{c|}{$\begin{array}{c}\text { Hay } \\
\text { package }\end{array}$} & \multicolumn{2}{c|}{$\begin{array}{c}\text { Green forage } \\
\text { package }\end{array}$} & \multicolumn{2}{c|}{$\begin{array}{c}\text { Urea } \\
\text { package }\end{array}$} & \multicolumn{2}{c|}{$\begin{array}{c}\text { Molasses } \\
\text { Package }\end{array}$} & \multicolumn{2}{c|}{$\begin{array}{c}\text { Non-adoption } \\
\text { package }\end{array}$} \\
\cline { 2 - 12 } & $\mathbf{N}$ & $(\%)$ & $\mathbf{N}$ & $(\%)$ & $\mathbf{N}$ & $(\%)$ & $\mathbf{N}$ & $(\%)$ & $\mathbf{N}$ & $(\%)$ & $\mathbf{N}$ & $(\%)$ \\
\hline indigenous & 174 & 50 & 54 & 15.52 & 56 & 16.09 & 19 & 5.46 & 0 & 0 & 45 & 12.9 \\
Crossbred & 693 & 64.89 & 210 & 19.66 & 82 & 7.68 & 34 & 3.18 & 14 & 1.3 & 35 & 3.28 \\
Buffalo & 716 & 69.52 & 192 & 18.64 & 66 & 6.41 & 16 & 1.55 & 4 & 0.4 & 36 & 3.50 \\
Sheep & 100 & 39.68 & 73 & 28.97 & 51 & 20.24 & 8 & 3.17 & 0 & 0 & 20 & 7.94 \\
Goat & 100 & 52.91 & 38 & 20.11 & 32 & 16.93 & 0 & 0 & 0 & 0 & 19 & 10.10 \\
Donkey & 89 & 41.58 & 48 & 22.43 & 35 & 16.36 & 8 & 3.74 & 5 & 2.3 & 29 & 13.60 \\
\hline
\end{tabular}

Differences between packages for herd composition were significant $\left(\chi^{2}=743.9123, P<0.05\right)$

Table 4. Herd composition under the different governorates and regions

\begin{tabular}{|l|c|c|c|c|c|c|c|c|c|c|c|c|}
\hline \multirow{2}{*}{ Items } & \multicolumn{2}{|c|}{ Indigenous } & \multicolumn{2}{c|}{ Crossbred } & \multicolumn{2}{c|}{ Buffalos } & \multicolumn{2}{c|}{ Sheep } & \multicolumn{2}{c|}{ Goat } & \multicolumn{2}{c|}{ Donkey } \\
\cline { 2 - 11 } & $\mathbf{N}$ & $(\%)$ & $\mathbf{N}$ & $(\%)$ & $\mathbf{N}$ & $(\%)$ & $\mathbf{N}$ & $(\%)$ & $\mathbf{N}$ & $(\%)$ & $\mathbf{N}$ & $(\%)$ \\
\hline Nile Delta region & & & & & & & & & & & & \\
Sharqia & 67 & 19.25 & 390 & 36.52 & 346 & 33.59 & 56 & 22.22 & 65 & 34.39 & $\mathbf{4 7}$ & 21.96 \\
Monufia & 40 & 11.49 & 165 & 15.45 & 240 & 23.30 & 27 & 10.71 & 27 & 14.29 & 48 & 22.43 \\
Total region & $\mathbf{1 0 7}$ & $\mathbf{3 0 . 7 4}$ & $\mathbf{5 5 5}$ & $\mathbf{5 1 . 9 7}$ & $\mathbf{5 8 6}$ & $\mathbf{5 6 . 8 9}$ & $\mathbf{8 3}$ & $\mathbf{3 2 . 9 4}$ & $\mathbf{9 2}$ & $\mathbf{4 8 . 6 8}$ & $\mathbf{9 5}$ & $\mathbf{4 4 . 3 9}$ \\
Middle Egypt region & & & & & & & & & & & & \\
El-Fayoum & & & & & & & & & & & & \\
Minya & 133 & 38.22 & 290 & 27.15 & 242 & 23.50 & 35 & 13.89 & 53 & 28.04 & 63 & 29.44 \\
Total region & 108 & 31.03 & 223 & 20.88 & 202 & 19.61 & 134 & 53.17 & 44 & 23.28 & 56 & 26.17 \\
Total study area & $\mathbf{2 4 1}$ & $\mathbf{6 9 . 2 5}$ & $\mathbf{5 1 3}$ & $\mathbf{4 8 . 0 3}$ & $\mathbf{4 4 4}$ & $\mathbf{4 3 . 1 0}$ & $\mathbf{1 6 9}$ & $\mathbf{6 7 . 0 6}$ & $\mathbf{9 7}$ & $\mathbf{5 1 . 3 2}$ & $\mathbf{1 1 9}$ & $\mathbf{5 5 . 6 0}$ \\
\hline
\end{tabular}

Differences between regions and governorates for herd composition were significant $\left(\chi^{2}=743.9123, P<0.05\right)$

\section{Herd structure}

Our study revealed that the proportion of farmers adopting silage had the highest proportion of dairy cows about $51.54 \%$ vs $13.08 \%$ for the nonadopters. The same trend was observed for heifers, fattening, and growing cows, being $49.18 \%$, $52.17 \%$ and $46.59 \%$ vs $11.48 \%, 8.7 \%$ and $17.05 \%$ respectively. Generally speaking, the achieved result of the present survey revealed also that the highest percentage of dairy, heifer, fattening, and growing for crossbred cows and buffaloes was detected under silage, hay, and untraditional green forages comparable to those detected under nonadopters as shown in Table (5).

Regardless of the animal type and age, animal percentage under silage $(64.72 \%)$, hay $(18.64 \%)$, and untraditional green forages (8.34\%) was higher than those under the non-adopter category (4.7\%).
Data reflecting the herd structure under the studied governorate are presented in Table (6). ElFayoum governorate had the highest percentage of dairy $(36.92 \%)$, heifer $(40.98 \%)$, fattening $(39.13 \%)$ and growing (37.5\%) indigenous cows as compared to the other governorates. The interpretation for this may be due to the fact that these cows are very tolerant to the harsh environmental conditions (high ambient temperature) in this region. Regarding the crossbred cows, Sharqia governorate had the highest proportion of dairy $(34.73 \%)$, fattening (37.05\%), and heifers $(42.7 \%)$ as compared to the other governorates. Regardless of the animal type and age, Sharqia governorate had the highest number and consequently percentage of animals followed by El-Fayoum governorate as shown in Table (6). 
Table 5. Herd structure under the adopters of nutritional packages and non-adaptors

\begin{tabular}{|c|c|c|c|c|c|c|c|c|c|c|c|c|c|c|}
\hline \multirow{3}{*}{ Items } & \multicolumn{10}{|c|}{ Adopters of nutritional packages } & \multirow{2}{*}{\multicolumn{2}{|c|}{ Non-adopters }} & \multirow{2}{*}{\multicolumn{2}{|c|}{ Total }} \\
\hline & \multicolumn{2}{|c|}{ Silage } & \multicolumn{2}{|c|}{ Hay } & \multicolumn{2}{|c|}{ UGF* $^{\star}$} & \multicolumn{2}{|c|}{ Urea } & \multicolumn{2}{|c|}{ Molase } & & & & \\
\hline & $\mathbf{N}$ & (\%) & $\mathbf{N}$ & $(\%)$ & $\mathbf{N}$ & (\%) & $\mathbf{N}$ & (\%) & $\mathbf{N}$ & $(\%)$ & $\mathbf{N}$ & (\%) & $\mathbf{N}$ & $(\%)$ \\
\hline \multicolumn{15}{|l|}{ Indigenous cows } \\
\hline Dairy & 67 & 51.54 & 18 & 13.85 & 21 & 16.15 & 7 & 5.38 & 0 & 0 & 17 & 13.08 & 130 & 5.31 \\
\hline Heifer & 30 & 49.18 & 11 & 18.03 & 10 & 16.39 & 3 & 4.92 & 0 & 0 & 7 & 11.48 & 61 & 2.49 \\
\hline Fattening & 36 & 52.17 & 14 & 20.29 & 10 & 14.49 & 3 & 4.35 & 0 & 0 & 6 & 8.7 & 69 & 2.82 \\
\hline Growing & 41 & 46.59 & 11 & 12.5 & 15 & 17.05 & 6 & 6.82 & 0 & 0 & 15 & 17.05 & 88 & 3.6 \\
\hline \multicolumn{15}{|l|}{ Crossbred cows } \\
\hline Dairy & 270 & 66.5 & 75 & 18.47 & 29 & 7.14 & 13 & 3.2 & 8 & 1.97 & 10 & 2.46 & 406 & 16.6 \\
\hline Heifer & 89 & 64.96 & 20 & 14.6 & 15 & 10.95 & 6 & 4.38 & 0 & 0 & 7 & 5.11 & 137 & 5.6 \\
\hline Fattening & 159 & 63.35 & 64 & 25.5 & 15 & 5.98 & 3 & 1.2 & 6 & 2.39 & 4 & 1.59 & 251 & 10.26 \\
\hline Growing & 175 & 63.87 & 51 & 18.61 & 23 & 8.39 & 12 & 4.38 & 0 & 0 & 13 & 4.75 & 274 & 11.2 \\
\hline \multicolumn{15}{|l|}{ Buffalos } \\
\hline Dairy & 277 & 63.39 & 86 & 19.68 & 44 & 10.07 & 6 & 1.37 & 2 & 0.46 & 22 & 5.03 & 437 & 17.87 \\
\hline Heifer & 146 & 76.84 & 28 & 14.74 & 7 & 3.68 & 6 & 3.16 & 0 & 0 & 3 & 1.58 & 190 & 7.77 \\
\hline Fattening & 170 & 83.74 & 27 & 13.3 & 3 & 1.48 & 1 & 0.49 & 1 & 0.49 & 1 & 0.49 & 203 & 8.3 \\
\hline Growing & 123 & 61.5 & 51 & 25.5 & 12 & 6 & 3 & 1.5 & 1 & 0.5 & 10 & 5 & 200 & 8.18 \\
\hline Total & 1583 & 64.72 & 456 & 18.64 & 204 & 8.34 & 69 & 2.82 & 18 & 0.74 & 115 & 4.7 & 2446 & 100 \\
\hline
\end{tabular}

Differences between packages for herd structure were significant $\left(\chi^{2}=595.1971, P<0.05\right)$

$\mathrm{UGF}^{*}=$ Untraditional green forages

Table 6. Herd structure under the studied governorates.

\begin{tabular}{|l|c|c|c|c|c|c|c|c|}
\hline \multirow{2}{*}{\multicolumn{1}{|c|}{ Items }} & \multicolumn{7}{c|}{ Governorates } \\
\cline { 2 - 8 } & \multicolumn{2}{|c|}{ Sharqia } & \multicolumn{2}{c|}{ Monufia } & \multicolumn{2}{c|}{ El-Fayoum } & \multicolumn{2}{c|}{ Minya } \\
\cline { 2 - 9 } & $\mathbf{N}$ & $\mathbf{( \% )}$ & $\mathbf{N}$ & $(\%)$ & $\mathbf{N}$ & $\mathbf{( \% )}$ & $\mathbf{N}$ & $(\%)$ \\
\hline Indigenous cows & & & & & & & & \\
Dairy & 23 & 17.69 & 17 & 13.08 & 48 & 36.92 & 42 & 32.31 \\
Heifer & 13 & 21.31 & 7 & 11.48 & 25 & 40.98 & 16 & 26.23 \\
Fattening & 10 & 14.5 & 8 & 11.59 & 27 & 39.13 & 24 & 34.78 \\
Growing & 21 & 23.86 & 8 & 9.09 & 33 & 37.5 & 26 & 29.55 \\
Crossbred cows & & & & & & & & \\
Dairy & 141 & 34.73 & 68 & 16.75 & 108 & 26.6 & 89 & 21.92 \\
heifer & 39 & 28.46 & 26 & 18.98 & 46 & 33.58 & 26 & 18.98 \\
Fattening & 93 & 37.05 & 50 & 19.92 & 64 & 25.5 & 44 & 17.53 \\
Growing & 117 & 42.7 & 21 & 7.66 & 72 & 26.28 & 64 & 23.36 \\
Buffalos & & & & & & & & \\
Dairy & 144 & 32.95 & 95 & 21.74 & 107 & 24.49 & 91 & 20.82 \\
heifer & 62 & 32.63 & 25 & 13.16 & 64 & 33.68 & 39 & 20.53 \\
Fattening & 58 & 28.57 & 91 & 44.83 & 32 & 15.76 & 22 & 10.84 \\
Growing & 82 & 41 & 29 & 14.5 & 39 & 19.5 & 50 & 25 \\
\hline Total & $\mathbf{8 0 3}$ & $\mathbf{3 2 . 8 3}$ & $\mathbf{4 4 5}$ & $\mathbf{1 8 . 1 9}$ & $\mathbf{6 6 5}$ & $\mathbf{2 7 . 1 9}$ & $\mathbf{5 3 3}$ & $\mathbf{2 1 . 7 9}$ \\
\hline
\end{tabular}

Differences between governorates for herd structure were significant $\left(\chi^{2}=595.1971, \mathrm{P}<0.05\right)$ 
The results presented in Table (7) showed that the herd structure under the studied regions. The results showed that the highest percent of indigenous cows either as lactating (69.23\%), heifers (67.21\%), fattening $(73.91 \%)$ or growing $(67.05)$ was observed in Middle Egypt as compared to those in Nile Delta. On the other hand, Nile Delta had the highest percent of crossbred cows and buffaloes either as lactating (51.48\% and 54.69\%), fattening $(56.97 \%$ and $73.4 \%)$ or growing $(50.36 \%$ and $55.50 \%)$ respectively. Generally, regardless of the animal type and age, Nile Delta animal percentage was higher than those of Middle Egypt as indicated in Table (7).

\section{Milk production}

The data clearly showed that the average daily milk yield (DMY) recorded the highest significant $(P<0.05)$ value under the silage and urea adopter households compared to non-adopter households being $4.73,4.50$ and $2.65 \mathrm{~kg}$ per indigenous cow and $9.96,8.62$ and 5.28 per crossbred cow respectively. The same trend was observed for buffaloes, where the non-adopters recorded the lowest value of milk per day being $4.08 \mathrm{~kg}$ and the adopters of silage and Molase recorded the highest value of milk per day being 8.16 and $7 \mathrm{~kg}$, respectively as indicated in table 8 . The low average milk yields could be attributed to poor feed quality for the nonadopters. Khalil and Sammour (2006) found that the average milk yield of dairy animals before feeding the rations with corn silage was 7.32 $\mathrm{kg} /$ day/buffalo, it increased to $8.23 \mathrm{~kg} /$ day/ buffalo after feeding on corn silage. It was obvious that silage improved milk production by $0.91 \mathrm{~kg} /$ buffalo. The improvement in milk yield might be due to the fact that the concentration of neutral-detergent fiber (NDF) of corn silage ranges from 36 to $50 \%$, and the low concentration is desired. As ADF decreases, the digestibility and therefore the energy content increases. Beside the lignin content of corn silage is low and a range from about 2 to $4 \%$, low lignin content is desirable.

Khalil et al (2008) indicated that the daily milk yield for indigenous cows, crossbred cows and buffaloes was $4.27,5.36$, and $6.5 \mathrm{~kg} /$ day respectively. El-Sayes and El-Wardani (2004) reported that the average daily milk yield for local cow in Ismalia was $4.10 \mathrm{~kg} / \mathrm{day}$. Milk yields are affected by genetic, management and environmental factors (Msanga et al 2000).
In respect of lactation length (LL), as compared to non-adopters, farmers who adopt urea had the longest lactation period per native cow (200 days), while the non-adopters had the shortest lactation period per indigenous cow (166.15 days). Concerning crossbred cow, the data clearly showed that the longest lactation period was detected for farmers adopted silage (198.67 days) and hay (197.69 days) and the shortest lactation period was observed for the non-adopters group (171.42 days). On the contrary, the non-adopters who reared buffaloes had the longest lactation period (210 days), while urea (174 days) and molasses (150 days) adopters had the shortest lactation period. All the aforementioned differences were statistically significant $(\mathrm{P}<0.05)$ as shown in Table (8).

The survey results showed that non-adopters farmers obtained the lowest significant total milk yield from the indigenous cow $(437.30 \mathrm{~kg})$, crossbred cow (904.28 kg) and buffalo (867.50 kg) comparable to adopter farmers. Farmers who adopted silage recorded the highest significant total milk yield from crossbred cow $(1995.09 \mathrm{~kg}$ ) and buffaloes $(1584.15 \mathrm{~kg})$. Urea and silage adopters obtained the highest significant $(P<0.05)$ total milk yield for indigenous cows being 900 and $799.76 \mathrm{~kg}$ as compared to non-adopters $437.30 \mathrm{~kg}$ as shown in Table (8). Khalil et al (2008) and ElAshmawy et al (2006) indicated that total milk yield for buffalo was $1208.75 \mathrm{~kg} / \mathrm{L} . \mathrm{L} 1546.00 \mathrm{~kg}$ per L.L respectively.

Regarding parity (number of different times a female has had offspring), the results clearly showed that there is no significant difference between adopters of nutritional packages (silage, hay, urea, and molasses) and non-nutritional packages adopters. The aforementioned results were for indigenous cows and crossbred cows as indicated in Table (8). However, the difference was significant for buffaloes, the buffaloes under the non-nutritional packages adopters were in parity 4 , while buffaloes under urea adopters were in parity 2. It is worthy to mention that, parity definitely related to milk production. In this context, Epaphras et al (2004) demonstrated that milk production increased from parity 1 to 3 after which production dropped. Cows in $4^{\text {th }}$ and more lactations were no longer better producers compared to those in their $3^{\text {rd }}$ lactation.

In respect of calving interval $(\mathrm{Cl}$ is well-defined as the time from one calving to another). It was obvious that calving interval significantly $(P<0.05)$ increased for all dairy animals (indigenous cows, 
Table 7. Herd structure under the studied regions

\begin{tabular}{|l|c|c|c|c|c|c|}
\hline \multirow{2}{*}{ Item } & \multicolumn{2}{|c|}{ Nile Delta } & \multicolumn{2}{c|}{ Middle Egypt } & \multicolumn{2}{c|}{ Total } \\
\cline { 2 - 7 } & $\mathbf{N}$ & $\mathbf{( \% )}$ & $\mathbf{N}$ & $\mathbf{N}$ & $\mathbf{N}$ & $(\%)$ \\
\hline Indigenous cows & & & & & & \\
Dairy & 40 & 30.77 & 90 & 69.23 & 130 & 5.31 \\
Heifer & 20 & 32.79 & 41 & 67.21 & 61 & 2.49 \\
Fattening & 18 & 26.09 & 51 & 73.91 & 69 & 2.82 \\
Growing & 29 & 32.95 & 59 & 67.05 & 88 & 3.6 \\
Crossbred cows & & & & & & \\
Dairy & 209 & 51.48 & 197 & 48.52 & 406 & 16.6 \\
Heifer & 65 & 47.44 & 72 & 52.56 & 137 & 5.6 \\
Fattening & 143 & 56.97 & 108 & 43.03 & 251 & 10.26 \\
Growing & 138 & 50.36 & 136 & 49.64 & 274 & 11.2 \\
Buffaloes & & & & & & \\
Dairy & 239 & 54.69 & 198 & 45.31 & 437 & 17.87 \\
heifer & 87 & 45.79 & 103 & 54.21 & 190 & 7.77 \\
Fattening & 149 & 73.4 & 54 & 26.6 & 203 & 8.3 \\
Growing & 111 & 55.5 & 89 & 44.5 & 200 & 8.18 \\
\hline \multicolumn{1}{|c|}{ Total } & $\mathbf{1 2 4 8}$ & $\mathbf{5 1 . 0 2}$ & $\mathbf{1 1 9 8}$ & $\mathbf{4 8 . 9 8}$ & $\mathbf{2 4 4 6}$ & $\mathbf{1 0 0}$ \\
\hline
\end{tabular}

Differences between regions for herd structure were significant $\left(\chi^{2}=595.1971, P<0.05\right)$

Table 8. Productive and reproductive traits $(\mathrm{LSM} \pm \mathrm{SE})$ of dairy animals for adopters of nutritional packages and non-adopters

\begin{tabular}{|c|c|c|c|c|c|}
\hline \multirow[t]{2}{*}{ Items } & $\begin{array}{l}\text { daily milk } \\
\text { yield }\end{array}$ & $\begin{array}{l}\text { Lactation } \\
\text { length }\end{array}$ & Total milk yield & Parity & $\begin{array}{c}\text { Calving inter- } \\
\text { val }\end{array}$ \\
\hline & LSM \pm SE & LSM \pm SE & LSM \pm SE & LSM \pm SE & LSM \pm SE \\
\hline Indigenous cow & & & & & \\
\hline Silage & $4.73 \pm 0.17^{\mathrm{a}}$ & $169.28 \pm 4.28^{\mathrm{ab}}$ & $799.76 \pm 32.21^{\mathrm{a}}$ & $3.33 \pm 0.31^{\mathrm{Ns}}$ & $360.00 \pm 0.00^{\mathrm{ab}}$ \\
\hline Hay & $3.70 \pm 0.22^{b}$ & $174.50 \pm 7.79^{\mathrm{ab}}$ & $648.75 \pm 52.41^{\mathrm{b}}$ & $2.40 \pm 0.37^{\mathrm{Ns}}$ & $340.00 \pm 20.00^{b}$ \\
\hline Green forage & $3.57 \pm 0.17^{\mathrm{b}}$ & $175.38 \pm 8.88^{\mathrm{ab}}$ & $630.00 \pm 45.69^{b}$ & $3.23 \pm 0.28^{\mathrm{Ns}}$ & $366.15 \pm 5.37^{\mathrm{ab}}$ \\
\hline Urea & $4.50 \pm 0.00^{\mathrm{a}}$ & $200.00 \pm 0.00^{a}$ & $900.00 \pm 0.00^{\mathrm{a}}$ & $3.00 \pm 0.00^{\mathrm{Ns}}$ & $360.00 \pm 0.00^{\mathrm{ab}}$ \\
\hline Molasses & - & - & - & - & - \\
\hline Non-adopters & $2.65 \pm 0.13^{c}$ & $166.15 \pm 11.57^{\mathrm{b}}$ & $437.30 \pm 31.81^{c}$ & $3.00 \pm 0.50^{\mathrm{Ns}}$ & $387.00 \pm 11.74^{\mathrm{a}}$ \\
\hline Silage & $9.96 \pm 0.25^{\mathrm{a}}$ & $198.67 \pm 2.58^{\mathrm{a}}$ & $1995.09 \pm 65.91^{\mathrm{a}}$ & $3.26 \pm 0.14^{\mathrm{Ns}}$ & $360.00 \pm 0.00^{b}$ \\
\hline Hay & $6.90 \pm 0.35^{b}$ & $197.69 \pm 4.34^{\mathrm{a}}$ & $1367.69 \pm 78.48^{\mathrm{bc}}$ & $2.73 \pm 0.30^{\mathrm{Ns}}$ & $360.00 \pm 0.00^{b}$ \\
\hline Green forage & $5.21 \pm 0.52^{b}$ & $190.71 \pm 9.74^{\mathrm{ab}}$ & $1035.00 \pm 143.93^{\mathrm{cd}}$ & $2.42 \pm 0.48^{\mathrm{Ns}}$ & $361.42 \pm 1.42^{b}$ \\
\hline Urea & $8.62 \pm 0.45^{\mathrm{a}}$ & $182.50 \pm 14.36^{\mathrm{ab}}$ & $1590.00 \pm 162.11^{\mathrm{ab}}$ & $3.12 \pm 0.22^{\mathrm{Ns}}$ & $360.00 \pm 0.00^{\mathrm{b}}$ \\
\hline Molasses & $6.50 \pm 0.50^{b}$ & $187.50 \pm 22.50^{\mathrm{ab}}$ & $1185.00 \pm 75.00^{\mathrm{bcd}}$ & $2.25 \pm 0.25^{\mathrm{Ns}}$ & $360.00 \pm 0.00^{b}$ \\
\hline $\begin{array}{c}\text { Non-adopters } \\
\text { Buffalo }\end{array}$ & $5.28 \pm 0.18^{b}$ & $171.42 \pm 8.57^{b}$ & $904.28 \pm 48.73^{d}$ & $3.14 \pm 0.34^{\mathrm{Ns}}$ & $388.57 \pm 16.09^{a}$ \\
\hline Silage & $8.16 \pm 0.20^{\mathrm{a}}$ & $193.07 \pm 2.18^{\mathrm{ab}}$ & $1584.15 \pm 45.23^{a}$ & $3.52 \pm 0.16^{\mathrm{ab}}$ & $360.00 \pm 0.00^{\mathrm{ab}}$ \\
\hline Hay & $6.58 \pm 0.19^{b}$ & $192.00 \pm 5.76^{\mathrm{ab}}$ & $1260.86 \pm 53.39^{a b}$ & $3.65 \pm 0.30^{\mathrm{ab}}$ & $355.44 \pm 4.71^{b}$ \\
\hline Green forage & $5.97 \pm 0.14^{b}$ & $187.72 \pm 7.11^{\mathrm{ab}}$ & $1122.73 \pm 49.82^{\mathrm{bc}}$ & $3.90 \pm 0.41^{\mathrm{ab}}$ & $377.72 \pm 17.72^{\mathrm{ab}}$ \\
\hline Urea & $6.60 \pm 0.24^{\mathrm{b}}$ & $174.00 \pm 6.00^{\mathrm{bc}}$ & $1152.00 \pm 72.00^{\mathrm{bc}}$ & $2.20 \pm 0.20^{b}$ & $360.00 \pm 0.00^{\mathrm{ab}}$ \\
\hline Molasses & $7.00 \pm 1.00^{\mathrm{ab}}$ & $150.00 \pm 0.00^{c}$ & $1050.00 \pm 150.00^{b c}$ & $2.50 \pm 0.50^{\mathrm{ab}}$ & $360.00 \pm 0.00^{\mathrm{ab}}$ \\
\hline Non-adopters & $4.08 \pm 0.28^{c}$ & $210.00 \pm 6.85^{a}$ & $867.50 \pm 72.52^{c}$ & $4.27 \pm 0.61^{a}$ & $402.00 \pm 12.00^{\mathrm{a}}$ \\
\hline
\end{tabular}

${ }^{\mathrm{Ns}-\mathrm{a}-\mathrm{b}-\mathrm{d}}$ Means, within the row, with different superscripts differ significantly $(\mathrm{P}<0.05)$ 
Table 9. Productive and reproductive traits (LSM $\pm S E)$ of dairy animals under the studied governorates and regions

\begin{tabular}{|c|c|c|c|c|c|}
\hline \multirow[t]{2}{*}{ Item } & $\begin{array}{l}\text { daily milk } \\
\text { yield }\end{array}$ & $\begin{array}{l}\text { Lactation } \\
\text { length }\end{array}$ & Total milk yield & Parity & $\begin{array}{c}\text { Calving inter- } \\
\text { val }\end{array}$ \\
\hline & $\mathrm{M} \pm \mathrm{SE}$ & $\mathrm{M} \pm \mathrm{SE}$ & $\mathrm{M} \pm \mathrm{SE}$ & $\mathrm{M} \pm \mathrm{SE}$ & $\mathrm{M} \pm \mathrm{SE}$ \\
\hline \multicolumn{6}{|c|}{$\begin{array}{l}\text { Native performance } \\
\text { Region }\end{array}$} \\
\hline Nile Delta & $4.05 \pm 0.25^{\mathrm{a}}$ & $160.83 \pm 3.45^{\mathrm{b}}$ & $657.22 \pm 47.44^{\mathrm{Ns}}$ & $3.38 \pm 0.33^{\mathrm{Ns}}$ & $362.94 \pm 12.18^{\mathrm{Ns}}$ \\
\hline $\begin{array}{l}\text { Middle Egypt } \\
\text { Governorates }\end{array}$ & $3.76 \pm 0.15^{b}$ & $177.26 \pm 4.96^{\mathrm{a}}$ & $667.32 \pm 31.57^{\mathrm{Ns}}$ & $2.92 \pm 0.21^{\mathrm{Ns}}$ & $363.88 \pm 2.71^{\mathrm{Ns}}$ \\
\hline Sharqia & $4.31 \pm 0.33^{\mathrm{a}}$ & $163.18 \pm 4.82^{\mathrm{Ns}}$ & $706.81 \pm 59.16^{\mathrm{a}}$ & $3.36 \pm 0.38^{\mathrm{Ns}}$ & $350.90 \pm 16.03^{b}$ \\
\hline Monufia & $3.64 \pm 0.38^{\mathrm{bc}}$ & $157.14 \pm 4.73^{\mathrm{Ns}}$ & $579.28 \pm 74.64^{b}$ & $3.42 \pm 0.64^{\mathrm{Ns}}$ & $385.00 \pm 15.86^{b}$ \\
\hline El-Fayoum & $4.10 \pm 0.15^{\mathrm{ab}}$ & $175.52 \pm 8.15^{\mathrm{Ns}}$ & $713.28 \pm 34.64^{\mathrm{a}}$ & $3.36 \pm 0.32^{\mathrm{Ns}}$ & $365.29 \pm 5.29^{\mathrm{ab}}$ \\
\hline Minya & $3.47 \pm 0.23^{c}$ & $178.69 \pm 6.23^{\mathrm{Ns}}$ & $629.34 \pm 49.35^{\mathrm{b}}$ & $2.56 \pm 0.25^{\mathrm{Ns}}$ & $362.63 \pm 2.14^{\mathrm{ab}}$ \\
\hline \multicolumn{6}{|c|}{ Crossbred performance } \\
\hline \multicolumn{6}{|l|}{ Region } \\
\hline Nile Delta & $8.52 \pm 0.32^{a}$ & $195.09 \pm 3.39^{\mathrm{Ns}}$ & $1673.64 \pm 73.24^{\mathrm{Ns}}$ & $3.03 \pm 0.16^{\mathrm{Ns}}$ & $362.85 \pm 2.31^{\mathrm{Ns}}$ \\
\hline $\begin{array}{l}\text { Middle Egypt } \\
\text { Governorates }\end{array}$ & $7.74 \pm 0.35^{\mathrm{b}}$ & $193.85 \pm 3.58^{\mathrm{Ns}}$ & $1532.46 \pm 85.26^{\mathrm{Ns}}$ & $2.87 \pm 0.17^{\mathrm{Ns}}$ & $361.52 \pm 1.31^{\mathrm{Ns}}$ \\
\hline Sharqia & $7.86 \pm 0.40^{b}$ & $195.88 \pm 4.51^{\mathrm{Ns}}$ & $1554.12 \pm 92.44^{\mathrm{bc}}$ & $3.02 \pm 0.24^{\mathrm{Ns}}$ & $361.03 \pm 1.03^{\mathrm{Ns}}$ \\
\hline Monufia & $9.59 \pm 0.49^{a}$ & $193.80 \pm 5.18^{\mathrm{Ns}}$ & $1867.14 \pm 109.92^{\mathrm{a}}$ & $3.04 \pm 0.21^{\mathrm{Ns}}$ & $365.50 \pm 5.50^{\mathrm{Ns}}$ \\
\hline El-Fayoum & $7.32 \pm 0.42^{b}$ & $189.31 \pm 5.41^{\mathrm{Ns}}$ & $1409.31 \pm 102.50^{\circ}$ & $2.89 \pm 0.22^{\mathrm{Ns}}$ & $360.40 \pm 0.40^{\mathrm{Ns}}$ \\
\hline Minya & $8.17 \pm 0.57^{b}$ & $198.57 \pm 4.59^{\mathrm{Ns}}$ & $1660.00 \pm 135.00^{\mathrm{ab}}$ & $2.85 \pm 0.28^{\mathrm{Ns}}$ & $362.85 \pm 2.85^{\mathrm{Ns}}$ \\
\hline \multicolumn{6}{|c|}{$\begin{array}{l}\text { Buffalo performance } \\
\text { Region }\end{array}$} \\
\hline Nile Delta & $7.29 \pm 0.20^{\mathrm{a}}$ & $191.81 \pm 2.66^{\mathrm{Ns}}$ & $1400.58 \pm 44.32^{\mathrm{a}}$ & $3.59 \pm 0.16^{\mathrm{Ns}}$ & $362.29 \pm 3.18^{\mathrm{Ns}}$ \\
\hline $\begin{array}{l}\text { Middle Egypt } \\
\text { Governorates }\end{array}$ & $6.48 \pm 0.22^{b}$ & $195.71 \pm 3.20^{\mathrm{Ns}}$ & $1268.29 \pm 48.97^{b}$ & $3.68 \pm 0.24^{\mathrm{Ns}}$ & $370.69 \pm 6.42^{\mathrm{Ns}}$ \\
\hline Sharqia & $7.51 \pm 0.26^{\mathrm{a}}$ & $193.84 \pm 4.24^{\mathrm{Ns}}$ & $1451.15 \pm 58.0^{\mathrm{a}}$ & $3.53 \pm 0.19^{\mathrm{Ns}}$ & $360.51 \pm 5.42^{\mathrm{Ns}}$ \\
\hline Monufia & $7.07 \pm 0.31^{\mathrm{ab}}$ & $189.73 \pm 3.21^{\mathrm{Ns}}$ & $1348.68 \pm 66.94^{\mathrm{ab}}$ & $3.65 \pm 0.26^{\mathrm{Ns}}$ & $364.28 \pm 3.04^{\mathrm{Ns}}$ \\
\hline El-Fayoum & $6.28 \pm 0.30^{c}$ & $191.42 \pm 5.02^{\mathrm{Ns}}$ & $1199.71 \pm 64.84^{b}$ & $3.51 \pm 0.36^{\mathrm{Ns}}$ & $362.81 \pm 2.81^{\mathrm{Ns}}$ \\
\hline Minya & $6.68 \pm 0.34 b^{c}$ & $200.00 \pm 3.91^{\mathrm{Ns}}$ & $1336.86 \pm 72.46^{\mathrm{ab}}$ & $3.85 \pm 0.31^{\mathrm{Ns}}$ & $378.33 \pm 12.30^{\mathrm{Ns}}$ \\
\hline
\end{tabular}

${ }^{N s-a-b}$ Means, within the column, with different superscripts differ significantly $(P<0.05)$

crossbred cows, and buffaloes) under nonnutritional packages adopters being 387, 388.57, and 402 days for the aforementioned animals, respectively Table (8).

The productive and reproductive traits of dairy animals under the different governorates and regions are shown in Table (9). Concerning the daily milk yield (DMY), there were significant differences between the studied governorates. Where, the highest value of daily milk yield for indigenous cows $(4.31 \mathrm{~kg})$ was detected under Sharqia governorate and the lowest one $(3.47 \mathrm{~kg})$ was observed in Minya governorate. Sharqia also recorded the highest significant value of daily milk yield $(7.51 \mathrm{~kg})$ for buffaloes. While, Monufia had the highest value of DMY being $9.59 \mathrm{~kg}$ for crossbred cows.

Regarding lactation length (LL), the difference between the four governorates was not statistically significant for the three types of dairy animals. It was obvious that Minya governorate recorded the highest insignificant value of lactation length being 178.69, 198.57, and 200 days for indigenous cows, crossbred cows and buffaloes respectively. As shown in Table (9) the highest significant total milk yield (TMY) for indigenous cows, crossbred cows, and buffaloes was in El-Fayoum $(713.28 \mathrm{~kg})$, Monufia $(1867.14 \mathrm{~kg})$, and Sharqia $(1451.15 \mathrm{~kg})$, respectively.

There was no statistically significant difference for parity number between the studied governorates either for indigenous cows, crossbred cows, or buffaloes as mentioned in Table (9). However, El-Minya had the lowest parity number for indigenous cows and crossbred cows being 2.56 and 2.85, respectively, whereas for buffaloes, El-Fayoum recorded the lowest parity number being 3.51 . 
In respect of calving interval, it seemed that indigenous cows had longer calving interval (385 days) in Monufia governorate than those in other governorates, the difference was statistically significant $(P<0.05)$. Nevertheless, there were no significant difference in calving interval for crossbred cows and buffaloes under the studied governorate. El- Monufia and El-Minya recorded the longest calving interval being 365.5 and 378.33 days for the crossbred cows and buffaloes respectively as indicated in Table (9).

Concerning regions, the achieved results of the present survey revealed that dairy animals reared under the Nile Delta had the highest significant daily milk yield (DMY) versus those under the Middle Egypt, where it was $4.05,8.52$, and $7.29 \mathrm{~kg}$ vs $3.76,7.74$, and $6.48 \mathrm{~kg}$ for indigenous cows, crossbred cows, and buffaloes, respectively. Also, it had the highest significant total milk yield per lactation (TMYL) for buffaloes, being $1400.58 \mathrm{~kg}$ as compared to that under Middle Egypt being $1268.39 \mathrm{~kg}$. Whereas, Middle Egypt had the longest significant lactation length for indigenous cows being 177.26 days vs 160.83 days for those in Nile Delta as shown ion (Table 9).

\section{Conclusion and Recommendation}

Dairy cattle farming in Egypt are composed mainly from smallholder traditional mixed farming system being managed in traditional ways. Understanding the adoption of technologies is crucial for animal production development success under rural conditions. Using of appropriate nutritional packages will reduce the shortage of feed, leading to a sustainable animal production. Consequently there will be a potential increase in the income of household from packages adoption as a strategy to improve the living standard of smallholder dairy cattle farmers. The core discovery of the study indicated that there was a significant advantage of nutritional packages on milk yield and the number of cattle. The overall knowledge about the appropriate feeding and management has a positive effect on the adoption level of farmers and the frequency of it. First, great attention should be given in altering and increasing the farmers' awareness, through putting the proper extension strategies to train the farmers. Ensuring a relation between farmers and researchers in research institutes is highly recommended.

\section{REFERENCES}

Adekambi, S.A., Diagne, A., Simtowe, F.P. and Biaou, G. 2009. The Impact of Agricultural Technology Adoption on Poverty: The Case of, NERICA Rice Varieties in Benin. Contributed paper prepared for presentation at the International Association of Agricultural Economists' conference, Beijing, China, August pp. 16-22.

Ashley K., Young, J.R., Kea, P., Suon, S., Windsor, P.A. and Bush, R.D. 2016. Socioeconomic impact of forage-technology adoption by smallholder cattle farmers in Cambodia. Animal Production Science, https://doi.org/10.1071/AN16164

Bharathidasan, S. Walli, T.K. and Balakrishnan. V. 2007. Feed resources and feeding practices in Tamil nadu and the scope for nutritional interventions for increasing the productivity of dairy animals. Indian Dairyman 59(6), 39-45.

Chatterjee, A., Singh, R.B., Saha, R.C. and Roy, P.K. 2007. Feeding practice and nutritional status in dairy cattle in rural households of old Alluvial zone in West Bengal. Indian J. Dairy Sci. 60(6), 408-412.

Chikura, S. 1999. An assessment of the role of goats in a smallholder crop-livestock production system of Zimbabwe. A Case Study of Wedza Communal Area. MPhil Thesis, University of Zimbabwe, Harare, Zimbabwe, pp. 39-43.

Duncan, D.B. 1955. The Multiple Ranges and multiple F-Tests. Biometrics, 11, 1-42.

El-Ashmawy, M.M.I., Sammour, H.B., Khalil, M.A., El-Wardani, M.A. and Abdel-Aziz, Y.A. 2006. Comparative Technical and Economic Study of Dairy Farming Systems in West Delta Region. Proceedings of The $13^{\text {th }}$ Conference of the Egyptian Society of Animal Production Cairo Univ., Egypt, pp. 303-323.

El-Sayes M.F. and El-Wardani, M.A.A. 2004. Dairy farm characteristics under mixed faring system in Ismailia governorate in Egypt. Egyptian J. of Animal Production, .41, 93-102.

Epaphras, A., Karimuribo, E.D. and Msellem, S.N. 2004. Effect of season and parity on lactation of crossbred Ayrshire cows reared under coastal tropical climate in Tanzania. Livestock Research for Rural Development 16(6), 4246.

Foltz, J. and Chang, H.H. 2002. The Adoption and Profitability of rbST on Connecticut Dairy Farms. American J. of Agric. Economics 84, 1021-1032. 
Khalil M.A., Amal S. Omar and Hamouda, R.E. 2015. Assessment feeding packages based on water efficiency for dairy buffalo farms under the mixed (crop / livestock) farming systems in Egypt. Egyptian J. Nutrition and Feeds, 18(2), 125-136.

Khalil M.A. and Sammour, H.B. 2006. Economics of some feeding packages application under mixed Production system at El-Behira Governorate. Egyptian J. Prod., 43, 325-339.

Khalil, M.A. and El-Ashmawy, M.M.I. 2008. Characterization of dairy farming systems in Upper Egypt. Egyptian J. Anim. Prod., 45, 4355.

Kiptot, E., Franzel, S., Sinja, J., and Nang'ole, E. 2015. Preference and adoption of livestock feed practices among farmers in dairy management groups in Kenya. ICRAF Working, p. 208. Nairobi, World Agroforestry Centre. DOI: http://dx.doi.org/10.5716/WP15675.PDF

McBride, W.D., Short, S. and El-Osta, H. 2004. The Adoption and Impact of Bovine Somatotropin on U.S. Dairy Farms." Review of Agric. Economics 26(4), 472-488.

Mohamed, A.M., Ahmed, S.E. and Yemesrach, A. 2004. Dairy development in Ethiopia. EPTD discussion paper No. 123, International Food Policy Research Institute, Washington, DC, USA. pp. 1-58.
Msanga, Y.N., Bryant, M.J., Rutam, I.B., Minja, F.N. and Zylstra, L. 2000. Effect of environmental factors and of the proportion of Holstein blood on the milk yield and lactation length of crossbred dairy cattle on smallholder farms in north-east Tanzania. Trop. Anim. Health Prod., 32(1), 23-31.

Quddus M.A. 2012. Adoption of dairy farming technologies by small farm holders: practices and constraints. Bang. J. Anim. Sci., 41(2), 124-135.

Sanchez, P.A., Denning, G.L. and Nziguheba, G. 2009. The African Green Revolution Moves Forward. Food Security, 1, 37-44.

SAS, 2010. SAS User's Guide: Statistics. Version 9.1. SAS Inst. Inc., Cary, NC., USA.

Shalaby, T.H., El-Wardani, M.A., Sammour, H.B., Khalil, M.A., Ahmedand, A.M. and ElSayes, M.F. 2005. Economic study of different types of dairy cattle under mixed farming system in Egypt. Proceeding of Second Conference of Animal Production Research Institute and Regional Symposium on Buffalo Production. Sakha, Kafr El-Sheikh, Egypt, pp. 27-29.

Snedecor, G.W. and Cochran, W.G. 1993. Statistical methods ISBN: 0-8138-1561-4, pp. 9981000. 